\title{
UANG DAN FUNGSINYA (Sebuah Telaah Historis dalam Islam)
}

\author{
Wahyuddin*
}

\begin{abstract}
Abstrak
Konsep uang dalam ekonomi Islam berbeda dengan ekonomi konvensional. Dalam ekonomi Islam, konsep uang sangat jelas dan tegas bahwa uang adalah uang, uang bukan capital. Sebaliknya, konsep uang yang dikemukakan dalam ekonomi konvensional tidak jelas. seringkali istilah uang dalam perspektif ekonomi konvensional diartikan secara bolak-balik, yaitu uang sebagai uang dan uang sebagai capital.

Kata nuqud (uang) tidak terdapat dalam Al-Qur'an maupun hadist Nabi saw, karena bangsa Arab umumnya tidak menggunakan kata nuqud untuk menunjukan harga. Mereka menggunakan kata dinar untuk menunjukan mata uang yang terbuat dari emas, kata dirham untuk menunjukan alat tukar yang terbuat dari perak. Mereka juga menggunakan kata wariq untuk menunjukan dirham perak, kata 'ain untuk menunjukan dinar emas. Sedang kata fulus (uang tembaga) adalah alat tukar tambahan yang digunakan untuk membeli barangbarang murah.

Bahwa uang yang digunakan oleh umat islam pada masa Rasulullah adalah dirham perak Persia dan dinar emas Romawi dalam bentuk aslinya, tanpa mengalami pengubahan atau pemberian tanda tertentu. Rasulullah pun tidak pernah membuat uang khusus untuk umat Islam. Dengan kata lain, pada masa itu belum ada apa yang disebut dengan "uang Islam".

Sejarah mencatat bahwa selain uang emas dan perak murni berlaku pula jenis uang lain, yaitu uang emas dan perak campuran, fulus, dan uang kertas. Uang campuran tersebut pada mulanya beredar secara terbatas, kemudian beredar secara luas terutama setelah Khalifah al-Mutawakkil dan memberlakukannya secara resmi. Namun demikian mata uang emas dan perak murni tetap berlaku sebagai mata uang resmi dan paling banyak beredar. Selanjutnya, sejalan dengan perkembangan kehidupan ekonomi dan keterbatasan persediaan emas dan perak, umat Islam sedikit demi sedikit meninggalkan emas dan perak beralih menggunakan uang campuran dan akhirnya menggunakan fulus
\end{abstract}

Kata kunci : Uang, fungsi, historis, Islam.

Konsep uang dalam ekonomi Islam berbeda dengan ekonomi

konvensional. Dalam ekonomi Islam, konsep uang sangat jelas dan tegas bahwa uang adalah uang, uang bukan kapital. Sebaliknya, konsep uang yang dikemukakan dalam ekonomi konvensional tidak jelas. seringkali istilah uang dalam perspektif ekonomi konvensional diartikan secara bolak-balik, yaitu uang sebagai uang dan uang sebagai kapital (Adiwarman 2006: 77).

\footnotetext{
* Dosen pada Jurusan MKU FMIPA ITS.
}

jsh Jurnal Sosial Humaniora, Vo. 2, No. 1, Juni 2009 
Ahmad Hasan menjelaskan bahwa kata nuqud (uang) tidak terdapat dalam Al-Qur'an maupun hadist Nabi saw, karena bangsa Arab umumnya tidak menggunakan kata nuqud untuk menunjukan harga. Mereka menggunakan kata dinar untuk menunjukan mata uang yang terbuat dari emas, kata dirham untuk menunjukan alat tukar yang terbuat dari perak. Mereka juga menggunakan kata wariq untuk menunjukan dirham perak, kata 'ain untuk menunjukan dinar emas. Sedang kata fulus (uang tembaga) adalah alat tukar tambahan yang digunakan untuk membeli barang-barang murah (Ahmad Hasan, 2005: 2).

Menurut Al-Ghazali dan Ibnu Khaldun, definisi uang adalah apa yang digunakan manusia sebagai standard ukuran nilai harga, media transaksi pertukaran, dan media simpanan.

Ada beberapa fungsi uang antara lain:

\section{Uang sebagai Ukuran Harga}

Abu Ubaid menyatakan bahwa dirham dan dinar adalah nilai harga sesuatu, sedangkan segala sesuatu tidak bisa menjadi nilai harga keduanya, sedangkan AlGhazali menegaskan bahwa Allah menciptakan dinar dan dirham sebagai hakim penengah diantara seluruh harta agar seluruh harta bisa diukur dengan keduanya. Dikatakan, unta ini menyamai seratus dinar, sekian ukuran minyak za'faran ini mempunyai seratus dinar maka keduanya kira-kira sama dengan satu ukuran dan keduanya bernilai sama.

Ibnu Rusyd menyatakan bahwa ketika seseorang sulit menemukan nilai persamaan antara barang-barang yang berbeda, jadikan dinar dan dirham untuk mengukurnya. Apabila seseorang menjual kuda dengan beberapa baju, nilai harga kuda itu terhadap beberapa kuda adalah nilai harga baju itu terhadap beberapa baju. Maka jika kuda itu bernilai lima puluh tentunya baju-baju itu juga harus bernilai lima puluh.

Ibn al-Qayyim mengungkapkan bahwa dinar dan dirham adalah nilai harga barang komoditas. Nilai harga adalah ukuran yang dikenal untuk mengukur harta maka wajib bersifat spesifik dan akurat, tidak meninggi (naik) dan turun. Karena 
apabila unit nilai harga bisa naik dan turun seperti halnya komoditas, tentu kita tidak lagi mempunyai unit ukuran yang bisa dikukuhkan untuk mengukur nilai komoditas.(Adiwarman, Ekonomi Makro Islami; 2006:80)

\section{Uang Sebagai Media Transaksi}

Uang menjadi media transaksi yang sah yang harus diterima oleh siapapun jika ia detetapkan oleh negara. Inilah perbedaan uang dengan media transaksi lain seperti cek. Cek juga berlaku sebagai alat pembayaran karena penjual dan pembeli sepakat menerima cek sebagai alat bayar. Begitu pula dengan kartu debet, kartu kredit, dan alat bayar lainnya. Pihak yang dibayar dapat saja menolak penggunaan cek atau kartu kredit sebagai alat bayar, sedangkan uang berlaku sebagai alat pembayaran karena negara mensahkannya.

Umar bin Khattab berkata "saat aku ingin menjadikan uang dari kulit unta, ada orang yang berkata 'kalau begitu unta akan punah, maka aku batalkan keinginan tersebut""

Sebaliknya, emas dan perak tidak serta merta menjadi uang bila tidak ada stempel (sakkah) negara. Imam Nawawi berkata: "makruh bagi rakyat biasa mencetak sendiri dirham dan dinar sekalipun dari bahan yang murni, sebab pembuatan tersebut adalah wewenang pemerintah. Kemudian dirham maghsyusah tersebut dapat diketahui kadar campurannya, maka boleh menggunakannya baik dengan kebendaannya maupun dengan lainnya. Adapun jika kadar campuran tersebut tidak diketahui, maka di sini ada dua pendapat, pendapat yang paling sahih mengatakan hukumnya boleh. Sebab yang dimaksudkan adalah lakunya di pasaran. Sedangkan campuran dari tembaga yang terdapat pada dirham tersebut tidak mempengaruhi sebagaimana halnya adonan”.(al Nawawi: 258)

\section{Uang Sebagai Media Penyimpanan Nilai}

Al-Ghazali berkata: "Kemudian disebabkan jual beli, muncul kebutuhan terhadap dua mata uang. Seseorang yang ingin membeli makanan dengan baju, dari mana dia mengetahui ukuran makanan dari nilai baju tersebut, berapa? Jual beli terjadi pada jenis barang yang berbeda-beda seperti dijual baju dengan 
makanan atau hewan dengan baju. Barang-barang ini tidak sama, maka diperlukan "hakim yang adil" sebagai penengah antara dua orang yang ingin bertransaksi dan berbuat adil satu dengan yang lain. Keadilan itu dituntut dari jenis harta, kemudian diperlukan jenis harta yang bertahan lama karena kebutuhan yang terus menerus. Jenis harta yang paling bertahan lama adalah barang tambang. Maka dibuatlah uang dari emas, perak, dan logam”(al Ghazali: 397)

Ibnu Khaldun juga mengisyaratkan uang sebagai alat simpanan. Ia menyatakan Allah swt. menciptakan dari dua barang tambang yaitu emas dan perak sebagai nilai untuk setiap harta. Dua jenis ini merupakan simpanan dan perolehan orang-orang di dunia kebanyakannya.

Dari ketiga fungsi tersebut diatas jelaslah bahwa yang terpenting adalah stabilitas uang bukan bentuk uang itu sendiri, uang dinar yang terbuat dari emas dan diterbitkan oleh Raja Dinarius dari Kerajaan Romawi memenuhi kriteria uang yang nilainya stabil. Begitu pula uang dirham yang terbuat dari perak dan diterbitkan oleh Ratu dari kerajaan Sasanid Persia juga memenuhi kriteria uang yang stabil. Sehingga, meskipun dinar dan dirham diterbitkan oleh bukan negara Islam, keduanya dipergunakan di zaman Rasulullah saw.

Dalam perkembangan selanjutnya ketika Daulah Islamiah merambah ke wilayah-wilayah yang lebih luas dan terjadi benturan pengaruh dengan Romawi dan Persia, maka akan muncul pemikiran untuk memiliki mata uang yang diterbitkan oleh pemerintahan Islam. Namun saat itu, pemerintahan Islam belum mempunyai kemampuan untuk mencetak mata uang didasari emas dan perak

\section{Uang dalam Sejarah Islam}

Dalam khazanah Hukum Islam, terdapat beberapa istilah untuk menyebut uang, antara lain: nuqud, atsman, dan fulus. Akan tetapi ulama fiqih pada umumnya lebih banyak menggunakan istilah nuqud dan tsaman daripada istilah lainnya. 
Para ulama berbeda pendapat dalam merumuskan pengertian nuqud. Sebagian mengartikannya dengan "semua hal yang digunakan oleh masyarakat dalam melakukan transaksi, baik dinar emas, dirham perak maupun fulus tembaga”. Ulama lain mendefinisikannya dengan "segala sesuatu yang diterima secara umum sebagai media pertukaran dan pengukur nilai”. Sementara itu, Qal'ah mengemukakan definisi yang memberikan penekanan pada aspek legalitas disamping juga memperhatikan aspek fungsi sebagaimana definisi di atas. Ia mengatakan "nuqud adalah sesuatu yang dijadikan harga (tsaman) oleh masyarakat, baik yang terdiri dari logam atau kertas yang dicetak maupun dari bahan yang lainnya dan diterbitkan oleh lembaga keuangan pemegang otoritas”. Atas dasar definisi ini ia berpendapat bahwa seandainya masyarakat dalam melakukan transaksi menggunakan unta sebagai alat pembayaran, maka unta tersebut tidak dapat dipandang sebagai uang (nuqud) melainkan hanya sebagai badal (pengganti) atau 'iwadh (imbalan). Hal itu karena sesuatu yang dipandang sebagai uang harus memenuhi sekurang-kurangnya dua syarat, pertama, substansi benda tersebut tidak bisa dimanfaatkan secara langsung melainkan hanya sebagai media untuk memperoleh manfaat, kedua, dikeluarkan oleh lembaga yang memiliki otoritas untuk menerbitkan uang seperti bank sentral.(Muh Rawas Qal'ah Ji: 199 : 23)

Walaupun dikalangan ulama cukup popular istilah nuqud untuk pengertian uang, ternyata kata itu tidak ditemukan dalam Al-Qur'an. Untuk menunjukan uang atau fungsinya, Al-Qur'an menggunakan beberapa istilah, antara lain: dirham, dinar, emas, dan perak. Kata dirham hanya disebutkan satu kali yaitu dalam QS. Yusuf ayat 20: “dan mereka menjual Yusuf dengan harga yang murah, yaitu beberapa gram saja...”. Dalam ayat ini selain dikemukakan dirham sebagai mata uang dan fungsinya sebagai alat pertukaran, disinggung juga bahwa penggunaan kata dirham dikalangan masyarakat saat itu berpatokan pada jumlah atau bilangan bukan pada nilainya.(Ibn al 'Arabi, Ahkam al Qur-an, juz 3 : 1079)

Sebagaimana dirham, kata dinar hanya disebutkan satu kali yaitu pada QS. Ali-Imron Ayat 75. Ayat ini selain menyebutkan dinar sebagai satuan mata uang 
tertentu untuk pengukur nilai, mengisyaratkan pula bahwa uang adalah penyimpan nilai.

Mengenai kata emas dan perak cukup banyak ditemukan dalam Al-Qur'an. Hal ini tampaknya disebabkan ketika Al-Qur'an diturunkan masyarakat banyak menggunakan emas dan perak dalam melakukan kegiatan transaksi. Emas disebutkan pada belakang tempat, antara lain dalam QS. At-taubah ayat 34. Ayat ini selain mengandung isyarat bahwa emas dan perak adalah satuan mata uang, alat pembayaran dan penyimpan nilai, juga mengandung larangan penimbunan uang karena akan berakibat mematikan fungsinya sebagai sarana kegiatan ekonomi. Sementara itu kata perak disebutkan enam kali dalam Al-Qur'an. Diantaranya adalah terdapat pada QS.Ali-Imron Ayat 14, QS. Al-Kahfi ayat 1.

Sejarah mencatat bahwa bangsa arab pada masa jahiliyah telah melakukan kegiatan perdagangan dengan negara-negara tetangga dikawasan utara dan selatan. Hal ini tersirat dalam firman Allah QS. Quraisy ayat 1-2. Ketika pulang, mereka membawa uang dinar emas dan dirham perak. Al-Baladzari menuturkan bahwa Dinar Heraklius (kaisar Byzantin) dan dirham baghli dari Persia telah masuk ke penduduk Makkah pada masa jahiliyah. Hanya saja, uang yang mereka gunakan untuk melakukan transaksi jual beli tersebut pada umumnya masih dalam bentuk tibr (butiran, belum dicetak sebagai mata uang).

Masyarakat Arab pada masa itu dalam menggunakan uang-uang yang ada, baik dinar emas maupun dirham perak didasarkan pada timbangannya, bukan pada bilangannya karena uang-uang tersebut tidak sama timbangannya. Mereka tidak membeda-bedakan antara (uang) yang sudah dicetak (madhrub), yang sudah dicap (masbuk) dengan yang masih berupa butiran (tibr). Semua bentuk itu mereka gunakan sebagai uang atas dasar bahwa ia adalah emas atau perak, dan tidak mengharuskan telah dibuat dalam bentuk khusus sebagai uang (resmi). (Adnan Khalid: 1988).

Ketika Islam datang, kegiatan dan sistem transaksi ekonomi yang sudah berlaku di tengah-tengah masyarakat dengan menggunakan uang-uang yang sudah beredar diakui oleh Rasulullah saw. Beliau mengakui uang-uang itu sebagai uang- 
uang yang sah, demikian juga sistem pertukaran barter dan pertukaran dengan barang komoditas tertentu yang diperlakukan sebagai uang (nuqud sil'iyah) seperti gandum, kacang sya'ir, dan kurma dibiarkannya sebagaimana sudah berjalan. Sikap Rasulullah tersebut tercermin dalam hadistnya, antara lain: “(jual beli) emas dengan emas, perak dengan perak, gandum dengan gandum, sya'ir dengan sya'ir, kurma dengan kurma, dan garam dengan garam yang (dilakukan antara) satu jenis (disyaratkan harus) sama (beratnya, dan dengan cara) tangan ke tangan. Apabila (yang diperjual belikan itu) berbeda jenis, lakukanlah jual beli itu sekehendakmu apabila dengan cara tangan ke tangan". (HR. Muslim dari Ubadah bin Shamit).

Dari keterangan di atas tampak bahwa uang yang digunakan oleh umat islam pada masa Rasulullah adalah dirham perak Persia dan dinar emas Romawi dalam bentuk aslinya, tanpa mengalami pengubahan atau pemberian tanda tertentu. Rasulullah pun tidak pernah membuat uang khusus untuk umat Islam. Dengan kata lain, pada masa itu belum ada apa yang disebut dengan "uang Islam"(Ibn alQayyim: 1977).

Kebijakan Nabi saw umtuk tidak menerbitkan mata uang tertentu, selain karena kesibukannya dalam melakukan dakwah dan jihad, juga merupakan siyasah syar'iyah (politik hukum Islam). Sebab, seandainya Nabi memerintahkan agar mata uang yang sudah ada (beredar) sebelum berdiri negara Islam tidak dipakai dan menggantinya dengan mata uang Islam, tentu mata uang tersebut tidak akan diterima oleh masyarakat di luar wilayah Islam, dan hal itu akan menyebabkan umat Islam mengalami kesulitan dalam berbagai transaksinya. Sekalipun Rasulullah saw tidak pernah membuat uang tertentu untuk umat Islam, karena beliau mengakui dan memberlakukan mata uang emas dan perak yang berlaku ditengah-tengah bangsa arab, sebagaian besar ulama berpendapat bahwa emas dan perak adalah mata uang Islami bagi negara Islam, dan mata uang emas dan perak tersebut adalah nilai atau harga suatu barang sekalipun emas dan perak itu belum dicetak.(Adi Warman; $2006: 310$ ) 
Pada masa Khalifah Abu Bakar, uang yang berlaku pada masa Rasulullah tetap diberlakukan sebagaimana adanya tanpa mengalami pengubahan. Hal ini karena perhatian Khalifah Abu Bakar lebih tefokus pada penataan sendi-sendi pemerintahan dan memerangi orang murtad yang merupakan perioritas utama, disamping juga karena masa pemerintahanya yang singkat.

Khalifah Umar pada masa-masa awal pemerintahannya juga tetap memberlakukan sistem yang telah berjalan pada masa Abu Bakar. Barulah pada tahun 18 hijriyah atau tahun ke-6 dari pemerintahannya, ia memasukkan beberapa kata Arab pada uang Persia dan Romawi yang beredar. Ia membubuhkan namanya pada beberapa dirham dan menuliskan beberapa kata seperti "Bismillah, Alhamdulillah, Bismirobbi, Muhammad Rasulullah" dan kata-kata serupa lainnya yang menunjukkan simbol Islam. Namun bentuk uang tersebut masih tetap sama dengan bentuk aslinya sebagai uang asing yang memuat simbol-simbol non Islam. Sebelum itu Umar pernah berfikir untuk membuat dirham dari kulit unta, namun ketika rencana itu disampaikan ada beberapa sahabat yang memberi masukan bahwa jika rencana tersebut direncanakan, tentu unta akan habis dan akhirnya Umar membatalkan rencananya.(Ma'bid Ali; Nudhum al-Maliyah, j.2 :26)

Di era pemerintahan Bani Umaiyah, pembuatan uang masih tetap mengikuti jejak para pendahulunya yaitu memberlakukan mata uang dinar dari Byzantin dan dirham dari Sasanid dengan membubuhi beberapa simbol Islam. Pada masa awal dinasti Umaiyah ini pembuatan uang bukan merupakan otoritas pihak tertentu dalam pemerintahan, selain khalifah para gubernur dan pimpinan di daerah-daerahpun membuat uang khusus bagi wilayah masing-masing. Abdul Malik bin Marwan adalah khalifah pertama yang membuat dinar emas dalam jumlah yang terbatas, demikian pula Abdullah bin Zubair membuat dirham sendiri dan membubuhkan namanya. Hal yang sama juga dilakukan oleh saudaranya Mus'ab bin Zubair ketika menjadi gubernur di Irak (membuat dirham khusus) (Ibn Khaldun, Muqaddimah : 463).

Melihat kenyataan seperti itu, Abdul Malik bin Marwan melakukan upaya unifikasi mata uang di seluruh wilayah Islam setelah sebelumnya masing-masing 
gubernur membuat uang khusus. Pada tahun $76 \mathrm{H}$ proyek pembuatan uang khusus (Islami) yang bersih dari unsur dan simbol-simbol asing mulai dilakukan. Sejak saat itu, untuk pertama kali negara dan pemerintah terlepas dari uang asing. Kebijakan pembuatan uang Islami seperti itu dilanjutkan oleh pemerintahpemerintah sesudahnya walaupun terdapat perbedaan-perbedaan antara yang satu dengan yang lain dari sisi kualitas bahan, timbangan dan bentuk, serta tulisan yang dibutuhkannya. Kondisi yang demikian ini terus berlangsung hingga wilayah-wilayah Islam terlepas dari Daulah Utsmaniyah dan menjadi wilayah kekuasaan koloni. Pada saat itu mulailah uang kertas berlaku di hampir semua wilayah Islam.(Adnan Khalid ;62)

Sejarah mencatat bahwa selain uang emas dan perak murni berlaku pula jenis uang lain, yaitu uang emas dan perak campuran, fulus, dan uang kertas. Uang campuran tersebut pada mulanya beredar secara terbatas, kemudian beredar secara luas terutama setelah Khalifah al-Mutawakkil dan memberlakukannya secara resmi. Namun demikian mata uang emas dan perak murni tetap berlaku sebagai mata uang resmi dan paling banyak beredar. Selanjutnya, sejalan dengan perkembangan kehidupan ekonomi dan keterbatasan persediaan emas dan perak, umat Islam sedikit demi sedikit meninggalkan emas dan perak beralih menggunakan uang campuran dan akhirnya menggunakan fulus.

Bukti yang menujukkan bahwa fulus telah ada dan berlaku di negara Islam pada masa awal adalah fatwa-fatwa sebagian ulama tabi'in (generasi sesudah sahabat) tentang fulus ketika membicarakan masalah-masalah fiqih. Ibrahim anNaqha'i misalnya memberikan fatwa dengan kebolehan melakukan akad salam dengan fulus, Mujahid (w.102 H) memberikan fatwa bahwa pertukaran satu fulus dengan dua fulus adalah boleh jika dilakukan dari tangan ke tangan.

Pada masa itu, keberadaan uang fulus hanya merupakan uang penunjang yang digunakan untuk melakukan transaksi dalam nilai sedikit. Uang emas dan peraklah yang tetap menjadi uang utama. Pada waktu-waktu berikutnya, transaksi banyak dilakukan dengan fulus sehingga fulus menjadi uang yang banyak beredar. 
Bahkan pada masa kekuasaan Mamluk dan pada abad ke-7 dan ke-8 H, fulus menjadi uang utama (resmi) negara.

Mengenai uang kertas apakah pernah dikenal dan digunakan dalam negara Islam (pada masa lampau) para ahli berbeda pendapat. Sebagaian memastikan bahwa negara Islam tidak pernah menggunakannya, sementara sebagaian ahli yang lain berpendapat bahwa umat Islam telah pernah menggunakannya pada beberapa periode. Tanpa mengurangi perbedaan pendapat tersebut, sejarah mencatat bahwa pada masa akhir Daulah Utsmaniyah uang kertas telah beredar dan berlaku. Pada tahun $1254 \mathrm{H}$. pemerintahan Utsmaniyah menerbitkan mata uang kertas yang disebut “al-Qo'imah” dan berlaku selama 23 tahun.

\section{Penggunaan Dinar Menurut Fiqih}

Pandangan para ulama tentang emas dan perak sebagai uang (alat pertukaran). Sebagaian ulama memandang emas dan perak sebagai harga secara khilqah, maksudnya bahwa keduanya diciptakan Allah untuk dijadikan sebagai harga atau nilai, diantara yang berpendapat demikian adalah:

1) Al-Ghazali menyebutkan: "Allah menciptakan dinar dan dirham sebagai hakim (pemutus) dan mutawassith (penengah, mediator) terhadap harta-harta yang lain untuk mengukur nilai atau harganya"

2) Ibnu Khaldun mengatakan: "Allah menciptakan dua logam emas dan perak sebagai nilai bagi semua harta"

3) Sarkhasi menuturkan: "emas dan perak seperti apapun bentuknya diciptakan Allah sebagai substansi harga".

4) Sebagaian ulama bahkan sangat berlebihan dalam memandang emas dan perak sehingga menurut mereka tidak boleh membuat mata uang dari selain keduanya. Al-Maqrizi, misalnya menegaskan bahwa tidak pernah diperoleh suatu berita dari umat manapun yang menyatakan bahwa mereka telah membuat mata uang dari selain emas dan perak baik pada masa terdahulu maupun sekarang.(Adi Warman , 2006 ; 314) 
Terhadap pendapat-pendapat tersebut, Khayil Abdul Khafid Yusuf memberikan catatan sebagai berikut:

1. Penggunaan emas dan perak sebagai atsman (harga, nilai) oleh masyarakat sebenarnya didasarkan pada budaya dan tradisi ('urf) bukan didasarkan pada ketentuan syariah Islam. Islam yang datang kemudian mengakui apa yang sudah berlaku di tengah-tengah masyarakat dalam melakukan transaksi pertukaran, mulai dari sistem barter sampai dengan penggunaan emas dan perak sebagai uang. Diketahui pula bahwa Nabi s.a.w. tidak hanya mengakui emas dan perak sebagai alat dalam melakukan transaksi alat pertukaran, tetapi sistem barterpun tetap diakuinya dan tidak dilarang, hanya saja Nabi memberikan beberapa ketentuan-ketentuan tertentu bagaimana terhadap pertukaran emas dan perak.

2. Pernyataan al-Maqrizi, "tidak pernah diperoleh suatu berita dari umat manapun yang menyatakan bahwa mereka telah membuat mata uang dari selain emas dan perak, baik pada masa terdahulu maupun pada masa sekarang" tidak sesuai dengan kenyataan. Penggunaan emas dan perak sebagai uang hanya berlaku pada kurun waktu tertentu dalam sejarah panjang pemakaian uang. Selain itu, ketika masyarakat (umat Islam) telah meninggalkan uang emas dan perak, dan beralih memakai uang lain yang terbuat bukan dari uang emas dan perak, ulama berbeda pendapat (tidak terjadi ijma') mengenai setatus hukumnya. Artinya, ada ulama yang mengakuinya sebagai uang dan ada pula yang tidak mengakuinya. Hal itu menunjukkan bahwa sejumlah ulama mengakui keabsahan uang selain emas dan perak, (Adiwarman, $2006 ; 316$ ).

Secara garis besar pendapat ulama fiqih mengenai penggunaan mata uang bukan emas dan perak dapat dikelompokkan menjadi dua. Pendapat pertama, yang merupakan pendapat minoritas, menyatakan bahwa "Uang adalah masalah syariah yang pengaturannya tidak diserahkan oleh Allah kepada kehendak manusia. Allah telah memberikan batasan dan ketentuan serta menetapkan emas 
dan perak sebagai atsman (harga, nilai) dan nuqud (uang) yang wajib digunakan, serta tidak memberlakukan hukum nuqud pada selain emas dan perak".

Diantara ulama yang berpendapat demikian adalah Abu Hanifah, Abu Yusuf, ulama madzhab Maliki dalam pendapat yang tidak masyhur, sebagian ulama madzab Syafi'i, serta sejumlah ulama konteporer seperti Taqiyuddin alNabhani. Meraka mengemukakan beberapa argumentasi antara lain sebagai berikut:

1. Islam melarang melakukan penyimpanan (penimbunan) emas dan perak sebagaimana firman Allah QS. at-Taubah (9): 34.

Penyebutan emas dan perak secara khusus dalam ayat ini sebagai sesuatu yang dilarang untuk disimpan, padahal jenis harga tidak terbatas hanya emas dan perak, ini menunjukkan bahwa penyimpanan selain keduanya tidak dipandang sebagai penyimpanan. Atas dasar itu, dapat dipahami bahwa keduanya (emas dan perak) adalah naqd (uang).

Firman Allah QS. Ali imron (3): 14. Dalam ayat ini, emas dan perak dinyatakan sebagai al-qanathir al-muqantharah. Ini menunjukkan bahwa keduanya adalah sarana untuk mengukur nilai.

2. Semua ketentuan hukum Islam mengenai emas dan perak dikaitkan dengan fungsinya sebagai mata uang dan nilai barang (komoditi). Ini merupakan pengakuan bahwa emas dan perak adalah unit pengukur yang berupa uang dan menujukkan pula bahwa uang dalam Islam adalah emas dan perak.

3. Nuqud (mata uang) adalah alat ukur dalam melakukan pertukaran, dan Allah tidak menyerahkan alat ukur tersebut pada pendapat manusia, tetapi Ia telah menentukanya dengan uang tertentu yaitu emas dan perak. Ketentuan ini ditetapkan oleh Al-Qur'an, Sunnah, dan Ijma' (Nabhani ; 266).

Pendapat kedua; merupakan pendapat mayoritas ulama menyatakan bahwa nuqud dan atsman adalah persoalan tradisi dan praktek ('Urf Istilahi) yang digunakan oleh masyarakat dan tidak terbatas hanya pada materi atau bahan tertentu. Oleh karena itu khalifah Umar pernah akan merencanakan untuk 
membuat uang dari kulit unta sekalipun akhirnya dibatalkan karena adanya pendapat dari beberapa sahabat yang lain. Diantara ulama yang berpendapat demikian ini adalah Muhammad bin Hasan dari kalangan Madzab Hanafi, sebagaian ulama madzab Maliki, ulama Madzab Safi'i dan sebagian ulama Madzab Hanafi, demikian juga Ibnu Taimiyah, Yahya bin Sa'id dan sebagaian besar ulama kontemporer.

Argumen kelompok kedua ini antara lain:

1. Kaidah fiqih, "Hukum asal tentang sesuatu adalah boleh". Kaidah ini merupakan kaidah terpenting dibidang amalah yang disimbolkan dari sejumlah ayat dan hadits. Berdasarkan kaidah ini dapat ditegaskan dalam suatu hal yang dijelaskan kebolehannya dalam hadits tidak dimaksudkan untuk membatasi, kecuali ada dalil yang menunjukkan demikian, juga tidak berarti dilarang menciptakan sesuatu yang baru. Oleh karena itu dalam mengkaji hukum sesuatu yang baru, langkah yang harus dilakukan adalah mencari dalil yang mengharamkan, bukan dalil yang membolehkan. Dalam konteks mata uang, adalah dalil yang mengharamkan penggunaan uang selain emas dan perak? Ternyata tidak ada satupun dalil yang melarangnya, karena itu penggunaan uang selain emas dan perak hukumnya adalah boleh dengan status "halal asli".

2. Masalah uang merupakan masholih mursalah, yakni suatu kemaslahatan yang tidak ada dalil khusus yang melarang atau memerintahkan untuk mewujudkannya. Persoalan seperti ini oleh Islam diserahkan sepenuhnya pada ijtihad manusia sesuai dengan kebutuhan perkembangan manusia. Oleh karena itu Nabi saw tidak pernah mencetak uang khusus untuk umat Islam, bahkan sebaliknya beliau mengakui dan menerima mata uang yang berlaku ditengahtengah masyarakat.

3. Dalam hukum Islam terdapat kaidah yang menegaskan "hukum asal dalam persoalan ibadah adalah ta'abbud, yakni terikat dan harus mengikuti aturan yang harus ditetapakan tanpa perlu memperhatikan pada makna, semangat dan 
tujuanya; sedangkan hukum asal dalam adat (kebiasaan, non ibadah) adalah memperhatikan pada makna, semangat dan tujuan".

4. Rencana Umar bin Khattab untuk membuat mata uang dari kulit unta. Seandainya uang merupakan persoalan syariah, tentu Umar tidak akan berfikir untuk melakukan hal itu. Para sahabat yang diajak bermusyawarah pun tidak pernah menghalangi Umar atau memberikan pendapat bahwa pembuatan uang dari selain emas dan perak tidak dibenarkan oleh agama (Adiwarman ; 320)

\section{Kesimpulan}

Konsep uang dalam ekonomi Islam berbeda dengan ekonomi konvensional. Dalam ekonomi Islam, konsep uang sangat jelas dan tegas bahwa uang adalah uang, uang bukan capital. Sebaliknya, konsep uang yang dikemukakan dalam ekonomi konvensional tidak jelas. Seringkali istilah uang dalam perspektif ekonomi konvensional diartikan secara bolak-balik, yaitu uang sebagai uang dan uang sebagai capital

Uang (menurut Al-Ghazali dan Ibn Khaldun) adalah apa yang digunakan manusia sebagai standard ukuran nilai harga, media transaksi pertukaran, dan media simpanan. Ketika Islam datang, kegiatan dan sistem transaksi ekonomi yang sudah berlaku di tengah-tengah masyarakat dengan menggunakan uang-uang yang sudah beredar diakui oleh Rasulullah saw. Beliau mengakui uang-uang itu sebagai uang-uang yang sah,

Hal ini dapat dilihat ketika uang yang digunakan oleh umat Islam pada masa Rasulullah adalah dirham perak Persia dan dinar emas Romawi dalam bentuk aslinya, tanpa mengalami pengubahan atau pemberian tanda tertentu. Rasulullah pun tidak pernah membuat uang khusus untuk umat Islam. Dengan kata lain, pada masa itu belum ada apa yang disebut dengan "uang Islam"

Para ulama' berbeda pandangan tentang apakah mata uang dalam Islam hanya terbatas pada emas dan perak saja atau boleh menggunakan selain keduanya. Pendapat pertama; merupakan pendapat minoritas, menyatakan bahwa "Uang adalah masalah syari'ah yang pengaturannya tidak diserahkan oleh Allah kepada 
kehendak manusia. Allah telah memberikan batasan dan ketentuan serta menetapkan emas dan perak sebagai atsman (harga, nilai) dan nuqud (uang) yang wajib digunakan, serta tidak memberlakukan hukum nuqud pada selain emas dan perak". Pendapat kedua; merupakan pendapat mayoritas ulama menyatakan bahwa nuqud dan atsman adalah persoalan tradisi dan praktek ('Urf Istilahi) yang digunakan oleh masyarakat dan tidak terbatas hanya pada materi atau bahan tertentu. Oleh karena itu khalifah Umar pernah akan merencanakan untuk membuat uang dari kulit unta sekalipun akhirnya dibatalkan karena adanya pendapat dari beberapa sahabat yang lain

\section{Daftar Pustaka}

A. Karim, Adiwarman, Ekonomi Makro Islami, Jakarta, RajaGrafindo, 2006.

Hasan, Ahmad, Mata uang Islami: Telaah Komprehensif Sistem Keuangan Islami, Jakarta, RajaGrafindo, 2005

.Ali, Ma'bid, al-Nudhum al-Maliyah fi al-Islam, Maktab al-Tarbiyah, t. th/

'Arabi, Ibn, Ahkam al-Qur-an, Beirut, Darul Ma'rifah, t.th.

Ghazali, Ihya' Ulumuddin, Beirut, Dar al Ma'rifah.

Adnan, Khalid al-Turkamani, al-Siyasah al-Naqdiyah wa al-Mashrafiyah fi alIslam, Qman, Muassasah al-Risalah, 1988.

Khaldun, Ibn, al-Muqaddimah, Libanon, Dar al-Kitab Lubnan

Nabhani, Taqiyuddin, al-Nidham al-Iqtishadi, Dar al-Ummah, 1990

Nawawi, Raudlah al-Thalibin wa 'Umdah al-Muftin, Beirut, Maktab al-Islami, 1985

Qayyim, Ibn, I'lam al-Muwaqqi'in, Beirut, Dar al-Fikr, 1977 